Noshi Arif and Farakh A. Khan 105

\title{
Social Welfare, Health and Pakistan
}

\section{Noshi Arif and Farakh A. Khan}

Some would claim that charity is a core cultural trait of mankind. The urge to help others is a selfish act of survival of the group and hence individual security. In today's world, welfare has assumed a wider meaning and is linked with the economy of the state, the concept of human rights of society, structure of society and cultural expression of welfare. The state may be willing to contribute towards welfare but poor economic conditions may not allow welfare programmes or only allow low key programmes. With poor level of governance most welfare work comes to a standstill. In such situations the burden of poor economies can be shared by all rather than the poor alone. Human rights, as defined by the UN, impinge on the basic concept of welfare as seen by individual states. The right of all people to shelter, security, health, job, education as well as freedom to speak, associate and practice religion are concepts difficult to swallow for many societies and states. Social disparity may not allow many to grant rights to others. Yet social welfare is a practical arm of human rights and not an act of charity to be left to individual whims. In Islam, social welfare is the right of the underprivileged and not an act of charity extended by the state or individual. On the other hand the welfare of all the citizens of the state is vital for economic and social development. There are more than 94 indicators to measure social development. Each country's performance in this area can be monitored following each intervention.

Although social welfare had been debated by philosophers for a long time, it only became important after the Industrial Revolution in the 1840s. This was the time of the birth of modern cities with all its problems of communal living and compression of people into tight compartmental life, dynamics new to the first generation rural society. Since the Industrial Revolution started in England, the first city to cross the 2 million mark inhabitants a hundred years ago was London. The responsibilities of the new industrialised state was projected in the domain of social welfare of its people. Social welfare was the responsibility of the parish but with a large number of new towns, this became impractical. The Poor-Law Amendment Act was passed in 1834 and the Municipal Corporations Act in 1835. These were the basis of social welfare in the Britain of the future (Hill, 1997). Social welfare at the level of local government started in the middle of the $19^{\text {th }}$ century West and emerged as a profession. Social welfare work in the hospital started in Massachusetts General Hospital, USA in 1905 (Morales and Sheafor, 1989). Social welfare departments in hospitals in Pakistan started in 1963. 
106 The Lahore Journal of Economics, Vol.3, No.1

The concept of a welfare state was introduced in the 1910 budget by David Lloyd George and Winston Churchill which was blocked in the House of Lords. In the USA Child Welfare was started in 1912 and social welfare was introduced during the Roosevelt era in 1935. The Social Security Act of 1935 was a significant landmark for the US. WH Beveridge (1879-1963), born in Rungpur, now Pakistan) is considered as the father of the modern welfare state when he produced the Beveridge Plan in 1944. The Beveridge Plan recommending war on Want, Disease, Ignorance, Squalor, and Idleness formed the basis of post war liberalism (Dean, 1994). It was after World War II that the Labour Government in Britain put the theories of social scientists into practice with great enthusiasm. It was a combination of "Keyesian economics and Beveridgean social concern that gave the welfare state its strong political legitimacy and popular appeal". Health, education, housing, minimal wages, money for the unemployed, care of the handicapped and destitute were assured by the state.

Over the years the cost of welfare soared and the state economy could not sustain the rising cost of welfare. It was also realised that government social services were not cost effective. But most important economic growth in the 70 s was not sufficient to be able to sustain the increasing cost of the service. In the 80 s the stage was set for a free market economy and denationalisation of the major government social welfare organisations. The state shifted its stance on social welfare and privatised its major sectors even then the social security programme in 1992-93 was 31 per cent of government expenditure in UK. In the USA Social Welfare Programmes form more than half the total government spending. It is estimated that more than one third of the US population would be living below the poverty line without this support. Government squeeze on social welfare in the developed countries has been the cause of hardships to the poor of the society and increased the gap between the upper and lower segments of society. Malaysia uses 39.5 per cent of its spending on social welfare (Shivani, A. Pakistan after fifty: Some thoughts. Dawn. 2.2.98). Is the capitalist economic system a failure?

The comparative figures are not readily available for Pakistan. According to the World Bank Database, Pakistan's spending on social security dropped from 0.32 per cent in 1988 to 0.05 per cent in 1993 of the total government expenditure budget (Source: Internet). On the other hand, India spends 4.0 per cent on welfare. The meager welfare budget in Pakistan is supplemented by foreign welfare organisations and NGOs but authentic figures are not available.

Health was the main target of the new policies to be cut in the welfare budget in the UK. A new system was introduced which was more 
responsive to cutting costs and improving the quality of service. The waiting time for cold surgery was also to be shortened. The effect of the new system, still in its infancy, needs time for evaluation.

We need to explore the concept of charity and social welfare in our society without the cultural influences from outside, especially the British clergy who have been active in the subcontinent since the arrival of the East India Company in $1600 \mathrm{AD}$. Culture and religion have a deep effect on social welfare. The desire to give charity is motivated by attaining the favour of God for the next world. We draw wider inspiration from the religious concept of welfare but also function in the cultural domain as well which varies within the main culture. In Islam, apart from Zakat, charity (Infaq, Khairat) has been stressed a great deal. Zakat is compulsory and is levied as 2.5 per cent on assets while Infaq is a compulsory donation which one should part with when personal needs are fulfilled for 'relations, orphans, poor travelers and those who seek help...'. Infaq is an individual act of charity which is binding on Muslims but unlike Zakat the state may not be involved. Both, Zakat and Infaq, are thus compulsory for Muslims. In peoples' perception of Islam they are asked to look after the needy, cripples, blind, widows and orphans as an act of charity and not part of the right of the poor. On the other hand the needy must not ask for help. The people should identify those requiring help and they should be helped without any advertisement. The area covered is mainly health and social problems. People are thus ready to open free hospitals, free dispensaries, 'yateemkhanas' (orphanages) and homes for unmarried girls. Most of the medical institutions for the blind and the crippled besides dispensaries have been established by the people to fulfil Islamic injunctions. We are also very keen on donating money for the construction and maintenance of mosques (including madarassas), mazars, seri (hospice) and water points for drinking. People are also willing to donate or give Zakat to reliable individuals such as Edhi, Prof. Rizvi and Imran Khan for a good cause where they are confident that their donation will not be wasted. In the management of welfare by the state, unfortunately in Pakistan the government is not involved or its performance is negligible. Islam in Pakistan does not have a system similar to Christianity or Buddhism. Charity is left to the individual. We thus find people willing to donate to organisations or individuals of their choice but when it comes to establishing a sewerage system, the whole edifice collapses. Collective work for welfare is lacking in our acquired core culture. At our cultural level feeding of the poor directly or through the Mazar is common. Distribution of meat on Eid and other occasions to relatives and the poor is also considered as a pious act. Money when donated to patients of a medical ward is expected to be used for the feeding of the poor. There is a heightened sense of charity during the time of Ramazan, Eid and other religious occasions and many medical welfare 
108 The Lahore Journal of Economics, Vol.3, No.1

agencies are in competition. The leadership succumb to our culture and feel the need to be seen on TV and newspapers in the act of distribution of charity to the poor. On the other hand, people are most reluctant to give their time and effort in organising welfare work unless there is some clear material or spiritual benefit in terms of status or financial gains or a place in heaven for the organisers.

The major block against our efforts towards welfare work is our social order. It is significant to note that the words used for welfare are borrowed from Arabic, Persian and English since there are no equivalent words in the local language. In Punjab and Sindh we are willing to cater to our brethren but reluctant to indulge in welfare work for other castes and the Kami, where the latter form the majority of the population and are landless second class citizens. This hangover from our ancient culture is still strong, despite being declared as un-Islamic (acquired core culture), and is also seen in our system of governance. In Balochistan and NWFP, despite a high degree of equality, welfare is confined to the tribal levels. At the national level all females are second class citizens. Efforts of welfare by foreign agencies are hampered by the social inequalities in our society which they find difficult to comprehend or ignore. This is also responsible for our failure to eliminate poverty from our society, low level of education and other variables cited by people to highlight our poor performance in the social sector.

Approaching the $21^{\text {st }}$ century and existing in the new world order, all countries are exposed to the international media where human rights have emerged as a major issue. All countries are making pious statements and pose as champions of human rights. Pakistan has signed various UN charters of rights of women, children etc. [UN Declaration of Human Rights 1948, UN Declaration of the Rights of the Child (not signed by the USA and Somalia (Deen, 1998) and UN Convention on the Rights of the Child 1989 etc.]. The reality on the ground is totally different. Many schemes are launched to appease foreign donors or the IMF/World Bank for loans. As our monitory position deteriorates, the burden is passed on to the poor. Instead of tackling the root cause of poverty we have tried to throw safety nets for the poor. These nets are full of loopholes and have not been effective at the national level.

The Muslims of India also took the welfare model from the British in India. Islam was threatened by the new rulers who opened educational institutions and established welfare work for the people. The clergy was, in many places, openly encouraged to spread Christianity and the route taken was through establishing educational institutions and welfare work. Sir Syed Ahmed was quick to realise the plight of the Muslims in the changed world 
and countered it by opening an educational facility for the Muslims in Aligarh which was not to function on the traditional lines of the Muslim system of education.

In 1884 with only Rs. 344, Anjuman-i-Himayat-i-Islam (AHI) was established with the following objectives.

1. Education. Secular, religious and technical.

2. Social service for orphans, destitute women and children.

3. Promotion of Islamic culture including publishing literature and the Holy Quran.

The AHI responded to their objectives by opening two degree colleges, Tibbia College (with Khairati Shafakhana), six high schools and a junior model school. In the social sector AHI opened two orphanages (Darul Shafqat), home for destitute boys, girls and widows (Milli Darul Atfal) who had suffered during the partition of 1947 and opened a reformatory for wayward girls (Darul Aman). The AHI also opened a printing press and a publishing house. The AHI received a severe set back in 1972 when its educational institutions were nationalised. Unlike the UK where the state imitated the welfare and educational system of the Church without taking over their facilities, the state in Pakistan took over the welfare and educational commitment in the name of socialism and made a mess of it. The repercussions of that unwise move are still there and efforts of privatisation are being made as a consequence.

The concept of welfare of AHI was targeted to education so that the Muslims could compete with others in the new system brought in by the British. It was an economic necessity. Later the social sector was introduced to cater to the aftermath of the killing and rape of partition (1947). The whole was given the garb of Islam with titles which a common Pakistani does not understand.

The care of mental patients is another cultural divergence. The mad houses in the West were converted into mental hospitals and finally closed down in recent years when it was realised that the mental patients are worse off in these institutions rather than if they are allowed to function in the community. Mental hospitals were opened by the British in India but were never popular, most mental patients were managed at home and only the destitute were admitted. The first mental hospital in Lahore was opened where the Senate Hall of the Punjab University is located in old army barracks in the 1850 s. 
Another aspect of welfare is the Mazar/Darbar system which functions around the graves of saints. These places offer food and security to the needy. The Mazars/Darbars are now run by the government and not the descendants of the saint. Food is donated as an act of piety for which God will reward the donor in this or the next world. It is not surprising that these places are full of junkies and labourers from outside the main city who have no place to go. In Gujrat, the Shah Daula Mazar is a refuge for microcephalic children providing shelter, food and security. Thus abnormal children are cared for under religious sanctity. In the village culture the wayfarers have a right to ask for food and shelter at any house, although this custom is fast disappearing. The local chaudhary of the village is also proud to run an open kitchen (langar) for the travelers and destitute with great pride.

The concept of social welfare is present in all religions of the world. In Islam we have to distribute 2.5 per cent of our assets to the poor in the form of Zakat but no system had been laid down for distribution and this aspect was left to the individual during British rule. The government is presently collecting Zakat annually from fixed deposits from the banks and is also responsible for its distribution. Usher collected from the landowners is put into the Zakat Fund. Bait-u1-Mal is another state run institution where the poor can be assisted financially. The identification of people and institutions requiring Zakat assistance is also debatable. Some would argue that the state is empowered to use Zakat for the purchase of armaments and other state expenditure. The religious schools are also eligible for funding from Zakat. Today, in Pakistan, Zakat and Bait-ul-Mal are basically agencies distributing money and are only marginally involved in the running of institutions. The method of collection and distribution of Zakat and Usher is debated by different schools of thought within Islam (Quddus, 1989).

There is also controversy on the collection of Zakat from Muslims living in a non-Muslim country, especially if the people pay their taxes for the welfare system of the state. In religions with an organised clergy, Christianity, Buddhism etc. the distribution and collection of alms/charity is the duty of the clergy and hence they have a system of distribution. Remnants of christian charity in the form of hospitals and educational institutions are still functioning in Pakistan. During the pre-British period the mosque was the centre of learning and was endowed with funds by the community to impart religious education and many still do. The Al Azhar University, the oldest in the Muslim world, still has a hospital and a teaching institution attached to it, although these institutions are run on the modern Western concept of health and education. The rise of humanism and later socialism, distinct from religion in the West, have been a recent phenomena. In the modern West the state has copied the existing system of 
the Church and taken over this responsibility as well in the form of a 'welfare state' and expanded the scope to education, housing, jobs, health, aid to the disabled, etc. The concept of welfare reached its peak in the socialist and communist states. Even in a non-communist country such as India the welfare system is outstanding in the communist state of Kerala where the literacy rate has reached 96 per cent. Although the states responsibility in the welfare of the needy is under scrutiny in the West due to the new fad of the free market economy and economic crunch combined with abuse of the system, the state however, has not completely divorced itself form this function. On the other hand the former communist states are retreating rapidly in the garb of free market economy and want the social sector to go on sale to the highest bidder to ease economic pressure. So far this policy line has been a human disaster.

Since the last 15-20 years government hospitals in Pakistan are the refuge of the poor and the well to do go for private hospitals. The government spends only 0.7 per cent of the GNP on the health of the nation. To discontinue this meager sum will not help ease the government's financial position but it will be a major disaster for the people of the country and may be a source of a backlash which would be difficult to handle politically.

Each department of a government hospital must have its own social welfare workers. These workers must care for the financial, social and psychological problems of the patients. In addition they should conduct research for the benefit of the patients. They should also be involved in fund raising for poor patients. A Drug Bank should be organised in the department under the charge of the Social Welfare officer for poor patients. Social welfare is a foreign concept where a stranger is to look after our financial and psychological needs where as we, in Pakistan, expect the children, relatives or friends to cater to our needs. The concept of the family as a unit of scrutiny is lacking to a major degree in the West and the state has to establish departments with experts in their institutions. Old people are expected to go into old peoples' homes because the young have not seen their elders being looked after and in any case the system of employment in the West does not allow for the care of aged parents. A worker in Pakistan is given leave immediately by the employer if he has to run errands for dependent parents. Similarly, the care of destitute children is undertaken by relatives or the society. The existing indigenous welfare system in Pakistan is not ideal and at times is brutal. We thus have little benefit from the Western concept of SOS villages and Fountain House which do not even touch the surface of poverty-related problems of children and mentally ill patients, while spending enormous amounts of money to rehabilitate a few. We also have to realise that help from a stranger i.e. 
social worker carries a grave stigma. People will gossip that "this unfortunate person has no one to look after him" and commonly call him a yateem a phrase used to express pity. People loath to receive charity. We thus see Western concepts of social welfare being applied to Pakistani problems and we get nowhere. Yet our society does not have institutionalised social welfare and the system often does not respond to the increasing financial requirements of modern hospital treatment. We must find ways of using our culture in the social sector to improve the well-being of our patients. We have to identify our present system of social welfare rather than import concepts from the West. We thus have to reinvent social welfare within the concept of our own culture. Unfortunately, we are steeped in Western books and training. Most of us believe that we will have to evolve according to the Western model and thus follow their concepts of welfare and also in other areas of development.

\section{Social Welfare and the Government}

In the past we have had a number of programmes for social welfare under the local government, changing names with each change of government but with the same result. The output of these schemes in terms of welfare for the poor has had no impact. Panchayat was an ancient system of local self government although it was not a representative body. The system is still unofficially functional in the rural heartland of Punjab. Lord Rippon in 1882 tried to revive the institution of the Panchayat i.e. empowerment of the people and decentralisation. After independence (1947) the Basic Democracy System (BD System) was introduced in 1959 again to empower the people at the 'grass roots'. Political interests rather than those of the people ruined the concept and the bureaucrat was given a supreme hand to kill dissent. The Rural Works Programme started in 1963 was changed to People's Work Programme and the BD System was scrapped in 1972 by the Peoples Party where the latter tried to introduce decentralisation and break away from the bureaucracy. The scheme failed to take off. Later the Agroville, Metroville and IRD Schemes were introduced with similar results (Quddus, 1989). During the Cold War era social welfare and communism were confused. To give greater power to the people and evolve decentralisation, in the minds of the American planners, might push the state towards communism, which was politically unacceptable for American interests at that time. In many states American interference toppled the governments who were trying to empower the people. Yet it was recognised that development was only possible through participation of the people. It was only in the late 90s that the American organisations, the World Bank, WHO and IMF were vocal about community participation and the needs of the people. People in power in Pakistan have always known that national development can only occur if 
the majority of the people participate in the development programmes but the hunger for absolute power is a major hurdle. The power to rule Pakistan was linked with the Americans. Today the Americans are seeking a communist agenda for social welfare to set the world in order. Can we respond to a new world order?

Social welfare is an alien concept in Pakistan. Yet the call ("food, shelter and clothes") for social welfare and involvement of the people in deciding their own destiny was the basis of the election victory of the Peoples Party government in 1969 in what was then West Pakistan. Although social welfare had been addressed as an issue earlier, the voter at that time was ready for change and the PPP won a resounding victory. The first UN adviser for social welfare was appointed in early 1952. It was only in 1955 when the Ministry of Social Welfare and Local Self Government was established, that the Urban Community Development projects and 1ater Rural Community Development projects were floated (Quddus, 1989). Their impact on the community was insignificant.

Social welfare in Pakistan has been given a tinge of Islam but in fact it is a political tool used by various governments and NGOs in their tussle for power and funds. Zakat and Usher were under the provincial Social Welfare Department. Later Zakat and Usher were centralised and given a separate identity when a different political party was in command in the Punjab. In response to the centralisation of Zakat, Bait-u1-Mal was created in the Punjab with the staff and umbrella of the provincial Social Welfare Department. In 1996 Bait-ul-Mal was separated from Social Welfare and made an independent body. Zakat and Usher were merged in 1997 and on December 26, 1997 Bait-ul-Mal was again given to the provincial Social Welfare Department (Bait-ul-Mal re-merged with Social Welfare Department. Hanif, I. Dawn. 28.1.98).

\section{Zakat Fund was established in 1981}

In the $68^{\text {th }}$ meeting of the Central Zakat Council (1995) the Zakat disbursement procedure were laid down and is being followed presently. The following categories of people/institutions are eligible for Zakat payment.

1. 'Guzara' allowance

2. Educational stipends

3. Stipends to deeni madaris

4. Health institutions 
5. Social welfare institutions

6. Jahez and rehabilitation

The Zakat Fund is thus to be utilised for social welfare and educational institutions. For health, the local Health Welfare Committee of the institution is entitled to sanction Rs. 200 for Out Door and Rs. 500 for In Door patients on a daily basis. However, patients requiring special sanction are also assisted. Zakat assistance is over and above the existing free treatment provided in government hospitals.

With chronic shortage of drugs in the government hospitals and treatment with expensive drugs requiring long term use, the Zakat Fund is of immense benefit. It gives access to treatment to the poor since there is no other source of funding for these poor patients. Cancer patients, renal transplantation and cardiac surgery patients find the Zakat Fund a source of new life. However, the Zakat Fund becomes a pawn in the national politics of the country and with each new government a new system is devised to suit the sitting authority. This is a time consuming process and while the Fund is not operative, the patients suffer. The Fund created in 1981 is still looking for a system.

Zakat, given to the deserving poor, amounts to Rs. 130 crore each year. This a large sum and its benefit in the form of Rs. 200/month is questionable. Perhaps we can devise better schemes for this fund which would eradicate poverty rather than promote it. (Zakat Act, 1991)

\section{Bait-ul-Mal (Established in 1991)}

It is unfortunate that in various publications the spelling for this important welfare organisation is different. This shows its importance or rather lack of importance. Bait-ul-Mal (BM) was the equivalent of the government treasury and was changed to 'Khazana' during British times. It was a general fund for running the government and its welfare schemes. The welfare part was for all the citizens of the domain in contrast to the Zakat Fund which was a contribution by the Muslims and used for their welfare alone. Today Bait-ul-Mal is a special fund given by the Federal government, although there are provisions for funding from other sources for welfare schemes and is directly under the Prime Minister. The ordinance was promulgated in 1991 (Pakistan Bait-ul-Mal Act, 1991) and the organisation established in 1992. Unlike Zakat, which is a financing agency for welfare only, Bait-u1-Mal is a participating agency as well. 
The declared functions of Bait-u1-Mal are as follows (Source: Bait-u1Mal pamphlet):

1. to provide financial assistance to the destitute, needy, widows, orphans, invalids, infirm and other needy persons,

2. to render help for the rehabilitation of the persons specified in Clause (a) in various professions or vocations,

3. to provide assistance to the children of the persons specified in Clause (a) for educational pursuits,

4. to provide residential accommodation and necessary facilities to the persons specified in Clause (a),

5. to provide free medical treatment of indigent sick persons and to set up free hospitals, poor houses and rehabilitation centres and to give financial aid to charitable institutions, including industrial institutions established especially for the poor and needy,

6. to provide stipends to educated youth during their training before their employment in jobs,

7. to provide stipends and financial assistance to brilliant but poor students who cannot afford to acquire higher technical or medical education abroad for lack of money,

8. to sponsor and promote self employment schemes,

9. any other purpose approved by the board with regard to the aims and objectives of the Bait-u1-Mal.

Like the Zakat Fund, Bait-u1-Mal also has a system of giving Rs. 200/ month/family to the needy under the Food Subsidy Scheme (established in 1994). The identification of this category of people is a difficult undertaking. People earning less than Rs. 1500/month are eligible but earnings per head per month are not considered. Earnings in terms of money is difficult in case of people living in the rural areas where the barter system is still in vogue. Personal whims, local politics and political pressures are operative and a great deal of money is wasted but there are few figures, only impressions. Bait-ul-Mal also supports an Atta Subsidy Scheme (started in January 1994) for the poor. The disbursement system has been made complicated to reduce corruption in its distribution. It is hoped that with the introduction of the card system it will reduce the misuse of this fund. 
From 1994-97 (up to February 1997) the expenditure on the Food Subsidy Scheme was Rs. 424,962,685 which amounts to Rs. 93.11 per head per year. There are three parallel schemes concerning food distribution with the BM (Food Stamp Scheme, Food Subsidy Scheme and Atta Subsidy Scheme). It seems that with each change of government the name is changed or a new welfare scheme is introduced. Now the Atta Subsidy Scheme has replaced the Food Subsidy Scheme of Bait-u1-Ma1. 520,000 families will get Rs. $200 /$ month (Rs. $10,4000,000 /$ month or Rs. $124,8000,000 /$ year) or 2600,000 people (taking 5 people as the family unit) will receive this subsidy which amounts to Rs. 480/year or Rs. 40/month per head. The forms are with the Bait-ul-Mal offices or the Khidmat-e-Khalq Committees (members to be nominated by the Deputy Commissioners). The Food Stamps are given to the poor who can purchase flour at a subsidised rate (The News, 29.12.97). The sole earner in the family should have an income less than Rs. 3,000 per month and have no additional source of income. This has to be verified by the MPA, Ilaqa magistrate or social worker. The Food Stamps were started on $1^{\text {st }}$ July, 1997 in Multan, Gujranwala and Jhung. In January, 1998 the scheme was extended to 100,000 families in Lahore and 6000 families in Rawalpindi. In the Punjab there are 4.57 million families living below the poverty line and the government has only been able to give Food Stamps to 7.1 per cent. The public response has not been satisfactory. About 50 per cent of the people have responded. The Punjab government is seeking Rs. 1.6 billion to extend the scheme (Punjab seeks Rs. 1.6 billion more from the centre for Food Stamps. Ahmed, M. The News. 16.2.98)

The organisation also runs schools to counter child labour in the country and are called National Centers for the Rehabilitation of Child Labour. The number of schools is limited (30 in the country, 10 in the Punjab) and their functional level needs to be determined. In any case the impact of their effort at the national level must be minimal. Unofficially, there are 3.2 million children involved in child labour. The organisation also runs Village Action Education Centers (18) in collaboration with the ILO in Sialkot and Narowal. Health funding is the most confused part of Bait-ulMal. There is a scheme of five Mobile Dispensaries in four large cities of each province, an idea which has failed in most instances. With the improved road system and transport of sorts available, the movement of people is now much more than before and a mobile dispensary in the city is of doubtful value. BM also funds the treatment of individual patients in government hospitals but there does not seem to be a system for selection of patients requiring funds. The network of existing health and educational facilities in the country are not the target of BM. 
$\mathrm{BM}$ is also involved in the training of the young in technical skills and advances loans for house building. The data is insufficient to assess its benefits.

Bait-ul-Mal seems to be a parallel welfare agency which is trying to participate in areas where it has neither the expertise nor an appropriate organisation to support its ventures. The staff may be well meaning but the task is beyond their capability. They try to merge the Islamic concept with the Western welfare system and attempt to impose it on our culture. Yet the concept as a religious act is beyond question. It may be an excellent public relations job for the governments image abroad and of some benefit for the local politicians, but is of little help for the poor of the country. On the other hand, as in the case of the Zakat Fund, national politics has a strong influence on the running of the organisation. Each new government tries to change the system and give new names to the on-going projects. The organisation is shifted to the centre or provincilised according to the dictates of election results.

It is sad to note that little solid research has been undertaken to see the benefits of Bait-ul-Mal and hence the failure or the success of the scheme is unknown.

\section{Usher}

Usher is an Islamic tax on agriculture started in 1981. The Central Zakat and Usher Committee appoints its agents/Namberdar in the rural areas to collect $U$ sher from the land owners. The rate of collection is 10 per cent of the produce in the well irrigated and 5 per cent of the produce in the canal irrigated lands. The agents determine the amount to be collected from the individual farmer. Collection of Usher is haphazard and arbitrary.

Government and Semi Government Schemes of Social Welfare in Punjab (Directorate of Social Welfare and Women Development, and Health Department)

We do not have access to the government welfare schemes and hence a comprehensive list of these could not be prepared. We also have no documents on the financial commitment of the government to welfare. Most of the information has been collected from newspapers or visits to some agencies.

Urban Community Development Projects (UCDP). The UCDP supervise and fund NGOs and government welfare schemes in the urban areas. 
There are more than 50 major government run social welfare schemes of a varied nature and of doubtful benefit to the community. A large number of these are for the benefit of the workers employed and are a source of political mileage. These need to be studied scientifically.

Social Action Programme (SAP), Phase II. In the SAP-I programme of 1992-93 Punjab spent about Rs. 85 billion (Dawn. 5.2.98) out of an allocation of Rs. 100 billion. So far the SAP-I programme has been of little benefit in improving the social indicators of Pakistan (Aleem, A. SAP-II and the World Bank. Dawn Economic and Business Review. 16-22, 1998; Sayed, A. Squander in the name of social development sector: the story of the Social Action Programme. The News 3rd May, 1998). A total of $\$ 10$ billion has been earmarked for the SAP-II programme for the next five and a half years starting in June, 1998. A sum of $\$ 8$ billion will be provided by the Pakistan government (1.8 per cent of GDP) and $\$ 2$ billion will be provided by various donor agencies as soft loans (Accord for $\$ 10$ billion SAP signed with WB donors. Dawn. 28.1.98). This is 58 per cent of the total health expenditure. The Department of International Development (UK) has pitched in $\$ 260$ million in the $\$ 2$ billion soft loan from foreign sources. Since this sum has been collected from British tax payers, there will be strict accountability. This is a new angle to aid/soft loans. The share of the Punjab will be $\$ 4$ billion.

Pakistan 2010 Programme (The News, 11.2.98). Launched by the Prime Minister on $10^{\text {th }}$ February 1998. The Programme has almost the same objectives as SAP-II, focusing on good governance. "The programme proposes six main steps to 'enterprise' Pakistan; (i) from distrust to partnership, (ii) from material based to knowledge based production, (iii) from protection to competition, (iv) from consumption to investment, (v) from state-controlled to customer-oriented services, and (vi) from injustice and intolerance to the opposite".

Significant goals envisaged in "Pakistan-2010" include: Doubling per capita income, promoting science and technology, strengthening the government at the grassroots level, improving law and order, enhancing the status of women, etc.

Pakistan has experienced similar plans before but with dismal failure. A Twenty-year Perspective Plan was launched in the mid 60's. A new Perspective Plan was launched in 1988 to take us to the year 2003. None of these plans were seriously followed and their impact on the social indicators was not seen. There are similar reservations of the present plan (Sheikh, A. Pakistan 2010 lacks adequate promise of social justice. The News, 16.2.98). 


\section{Health spending by the government}

The total health budget for the next 5 years will be Rs. 105 billion and Rs. 5 billion has been reserved for research, mainly for Health Services Research. The health budget is a form of subsidy for the poor. A School Health Programme was launched but its present status is not known. The Health Foundation was established in 1991 mainly to help unemployed doctors but it has not yet taken off.

\section{Foreign agencies and Primary Health Care}

Many foreign agencies in collaboration with local institutions are involved in Primary Health Care. This is rather odd because the developed world can better help us in Tertiary Health Care rather than in primary care. Primary Health Care should remain the responsibility of the government. Perhaps their help takes the pressure off our meager government health resources.

\section{NGOs and foreign donors}

Pakistan has over 10,000 NGOs targeting the welfare of the needy. The social welfare agencies are governed by the Voluntary Social Welfare Agencies (Registration and Control) Ordinance, 1961. NGOs deal with all aspects of social and religious welfare with different objectives. A large number of NGOs receive funds from foreign sources and from the government besides raising funds from there own sources. The federal government regulates these agencies and should have all the information. The performance of these agencies vary and should form a different subject for research (Ali, M. The NGO. Dawn, 14.2.98).

Foreign donor agencies work through recognised NGOs but also use the government structure for welfare work.

According to the UNDP "the quality of social services, such as health and education (in Pakistan), has worsened in the past decade" (1997). The agency was also critical of civil services and ineffective institutions where both had deteriorated since Independence. The World Bank has been active in Pakistan since 1952 pumping in $\$ 11$ billion. The Americans also experimented by sending volunteers in the Peace Corps programme in the early 60s, to improve the conditions of the people with American methods of working. It was a resounding failure.

In recent years the emphasis of the World Bank has shifted to projects on human resource development. Up to $1997 \$ 4.4$ billion worth of 42 projects have been funded of which the social sector projects form 25 
per cent. Major problems of Pakistan seem to stem from the loans by the donor agencies such as the IMF and the World Bank. Their impact on development was mainly negative since the projects did not really have any impact on the lives of the common people while they did have a major share in corrupting the services. These loans were used as a bribe to the Third World leadership during the Cold War period and became a serious liability after the demise of the Soviet Union. This scenario was neither in the minds of the donor agencies nor the Third World countries before 1990. A loan as a carrot now became a stick. It was hoped that the post 1990 Third World would see the writing on the wall and instead of squandering the loans would change their direction towards development through a process of good governance and then pay back the loans. It was soon realised that these countries had not changed direction and intervention by the donor agencies was required. By then the problems of governance had become almost insurmountable (Country Brief: Pakistan. The World Bank Group. Source: Internet. 1998).

The UNDP in 1995-96 launched the "Governance Programme or GOP” (Governance Programme, 1996. Source: Internet) and the driving force was the former Finance Minister of Pakistan, Dr. Mahbub-ul-Haq. It was argued that without human resource development economic and social development was not possible. 10.4 per cent of the 1995-96 budget was allocated but unfortunately 70 per cent of the allocation was consumed in salaries and allowances. The major thrust was of establishing the Institutional Reforms Group (IRP) and Social Action Programme (SAP). SAP was to target Primary Health Care (World Bank Report No. 16695 PAK, Nov. 1997), Population Welfare, Water and Sanitation and Basic Education. SAP was also to take care of nutrition, tuberculosis control, decentralisation and community participation and to improve the social structure targeting the poor and females. With the new government in power in 1997 this was renamed SAP-II. Associated with this will be the Environmental and Sustainable Livelihoods Programme and the Gender Programme. Meanwhile, the Pakistan government also asked for assistance for legal reforms (Strengthening the Legal and Judicial Process). The entire package was stuffed into the $8^{\text {th }}$ (1993-98) and later the $9^{\text {th }}$ Five Year Plans. Most important no time frame has been give for the expected change. In 1998 Rs. 230 million has been allocated to the Country Co-operation Framework (CCP) under the UNDP for Azad Jammu and Kashmir. The objective of CCP is "to co-ordinate and mobilise external resources for economic, social and environmental enhancement" (Dawn, 9.1.98).

The document was obviously prepared in the cool shade of Geneva and the model was of European developmental history which has little relevance to the Third World. The colonial period felt that all ills of the 
world could be solved by European style Christianity. Now it is the free market economy with good governance. The slogan has changed but the remedy is still far off the mark. Change in the attitudes and behaviour of society is not simply a matter of intervention resulting in predictable outcomes. Societies are too complex for simple solutions. One cannot transplant the European acquired core culture to the Third World. The UNDP document is as irrelevant to us as the dismal figures of our social indicators. The whole drama of fancy jargon used by the authors of UNDP reports are incomprehensible to the ordinary Pakistani and the solutions to our problems are figments of a European mind. But we need the loans to keep afloat. Under the existing circumstances we have done well. We fooled the donor agencies with sophisticated Arabic, Persian and English titles of welfare organisations which, in most cases, are not more than employment agencies for the Pakistani civil service. At the best we have used these for political gains. Yet we need human resource development to see Pakistan as an economically viable nation.

Historically, Pakistan launched its most ambitious project, the Village Aid Programme (1ater changed to Village Extension Services) in July 1952 with financial and technical assistance from the US targeting the rural population. This was the result of the Sufi Committee report published in 1951 which suggested almost the same remedies as the UNDP, IMF and the World Bank in the $90 \mathrm{~s}$ for welfare, community participation, local empowerment etc. of the rural population. The report suggested "a radical change in our thinking---the old concept of a benign and paternal government trying to do everything must be given up and replaced by the vital principle of self-help---to achieve practical results it will be necessary to translate objectives into concrete programmes based on the felt needs of the people. The people will draw up their own programmes". Perhaps the authors of this report did not anticipate the strong cultural resistance to a new concept and the programme was terminated in 1961 (Saeed, A. Selfgovernance through local bodies. The News 15.1.98).

Individual acts of charity (non formal welfare)

We cannot truly identify the magnitude of individual acts of charity since most people are not willing to publicise their donations. From our experience in the Department of Urology about 90 per cent of our patients get financial assistance from individuals. We thus see a substantial financial input by the community which is independent of formal sources of charity and may well be more than the government and non-governmental sources put together. 


\section{Conclusion}

Social welfare is considered as

Dynamics of Social Welfare

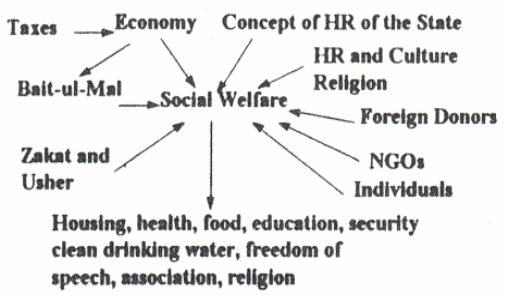
an act of charity which will increase the chances of entering heaven for the donor, whereas it is mandatory for the state and its people to provide welfare services for the poor and needy. Welfare is a basic human right and not charity and has been recognised as such in Islam.

The government in Pakistan has experimented with many aspects of collection of funds for welfare and their system of disbursement. The most effective system of collection has been with religious sanctions. Unfortunately religion does not give details of dispensation and there is disagreement on this issue. The political angle also confuses the system and misuse has been reported in the press. The experience with the NGOs and Deeni Madrassas have also not been encouraging in the utilisation of the funds collected. So far welfare funds have been best utilised in the health sector, but sudden termination of funds due to change of the government has been traumatic for patients dependent on this source for their very existence. Legally the fund cannot be stopped once the recipient is judged to be eligible for the Zakat Fund.

Bait-ul-Mal functioning, disbursement of funds and current schemes need to be rationally re-evaluated. The BM should become a lending bank of low interest rate for people with income below Rs. 1,500/month for long term benefit.

Since the creation of Pakistan a large number of charity hospitals, dispensaries, social welfare institutions and educational institutions have been established by the people of Pakistan. The government has its own welfare institutions (more than 33 institutions). Over the years multiple institutions have been created with functions which cross each others' paths. The impact of these institutions is not monitored and it is difficult to assess their usefulness in a country with mass poverty. Many institutions run by NGOs are not really functional and others are irrelevant. Some have clear political overtones and others try to imitate the ancient system of welfare. Some Deeni Madrassas are clearly violating human values in the name of Islam. The money doled out by the government welfare schemes such as Zakat and BM need to be studied and their long term benefits assessed since these schemes have been operational for many years. We need to conduct an in-depth independent study of the welfare organisations in the 
public and government sectors. We should be able to identify the immediate needs of our people and long term goals of these welfare organisations.

The role of politics and politicians in the welfare sector needs to be identified. There is a general impression that welfare agencies are used in enhancing the public image and in creating a vote bank rather than helping the poor. The utilisation of funds is also questioned by the people.

We have to finally take stock of the government machinery which is to implement government policies, (increase transparency and change the system of governance). If the implementing arm is incompetent or corrupt then no policy can succeed. We are back to good governance. There is a distinct feeling that we know what is to be done but fail to do it.

So far we have used our culture to fool the big agencies. Instead of using our culture these agencies have given us a package of foreign culture which can never work in Pakistan. Our acquired core culture will not allow this to happen. It is assumed that all societies will develop according to the European/American models and hence all the answers are with the West. It is further assumed that we have no system and need to become organised. We thus have to call in the 'experts' from the West. Funds for social development may well produce more disparity between the rich and the poor unless we can change the social order. It is not surprising that government efforts at welfare have not been successful. On the other hand, the peoples own welfare efforts have been successful although never recognised. In health and education the private sector has made government facilities irrelevant even at the level of the villages. The soft loans promised will be a liability for our future and siphoned through the established channels. The situation is similar to the economic development of the government sector which grew at a rate of 3 per cent in 1997 while the "black" economy is said to have produced 9 per cent growth. Why not duplicate and promote the existing systems evolved by the people of Pakistan? The answer has to come from within us and no one can help. We have to primarily address our existing social order (Khan, 1995) and change an ancient system to improve our future as a nation. This is a tall order. 


\section{References}

Dean, I., 1994. Social security, the cost of persistent poverty. In Social Policy Towards 2000. Edited by V. George and S. Miller. Routledge, London.

Deen, T. US right-wingers block ratification of UN treaty. Dawn, $19^{\text {th }}$ Feb. 1998.

Khan, F. A. Chaudhary-Kami culture. J. Research Society Pakistan. 32, No. 4: $25-29,1995$.

George, V. and Miller, S., 1994. Squaring the welfare circle. In Social Policy Towards 2000. Edited by V. George and S. Miller. Routledge, London.

Hill, M, 1997. Understanding Social Policy. $5^{\text {th }}$ edition. Blackwell Publishers.

Morales, A. and Sheafor, BW, 1989. Social work: a profession of many faces. Fifth edition. Allyn and Bacon, Boston.

Quddus, SA, 1989. Pakistan: towards a welfare state. Royal Book Company, Karachi.

Saeed, KA, 1998. Economy of Pakistan. Newfine Printing Press, Lahore, Pakistan.

World Bank Report No. 16695 PAK. "Pakistan: towards a health sector strategy. Health, Nutrition and Population, Unit, South Asia Region”. Revised - November, 1997. 